\title{
Romantic Palingenesis, or History from the Ashes
}

\author{
Benjamin Colbert* \\ Department of English, University of Wolverhampton, UK \\ *B.Colbert@wlv.ac.uk
}

\begin{abstract}
Palingenesis, or regeneration from decay, is variously invoked by eighteenth to early-nineteenthcentury natural philosophy, psychology, mythography, and literature. Its currency derives from the Swiss-French scientist Charles Bonnet's Palingénésie philosophique (1769), which conceives of natural history as repeated renewal after epochal catastrophes. Herder's Über die seelenwanderung (1782) develops an idea of "natural palingenesis" as the internal "rebirth" of selfhood within memory despite physiological decay. Pierre-Simon Ballanche's fragmentary magnum opus Essais de palingénésie sociale (1827-29) turned to political upheaval, locating the French Revolution within a process by which expiatory suffering gives birth to a new social order. Other writers looked back to alchemical experiments. Robert Southey reviewed these experiments in Omniana (1812) under the heading, "Spectral Flowers," and still other writers explored the palingenetic properties of resurrected bodies and ghosts. In the light of this not altogether unified discourse, this paper will consider the more discontented, sceptical, at times satiric, strain within Shelley's poetry, where beautiful idealisms of progressivist transformation do not entirely overcome the fact of death, decay, degeneration, and loss that is their substrata.
\end{abstract}

Shelley's last poem, "The Triumph of Life" (1822), is a Dantesque fragment in which a visionary poet encounters a maenad dance of captives following blindly a triumphal chariot driven by a hooded four-faced Janus. "And what is this?" the poet reasonably asks, and a voice answers: "Life" (Shelley's Poetry and Prose [hereafter SPP] line 180). The deformed, degenerate Rousseau that becomes the poet's guide is the Rousseau whose lustre was tarnished by the scandalous Confessions (1781), but also a Rousseau who lays aside the cherished illusions of Romantic idealism (McGann) and tragically accepts that the spirit cannot outstrip the flesh, that imagination remains earthbound rather than unbound. Refined beyond self-delusion by this 
knowledge, this Rousseau offers another kind of confession, one that both describes history as repeated error and disillusionment, and circumscribes consciousness within the human vessel. Insight in the poem is achieved through oblivion; vision requires a death or death-like sleep. Shelley thus figures vision as erasure:

["]And suddenly my brain became as sand

"Where the first wave had more than half erased The track of deer on desert Labrador,

Whilst the fierce wolf from which they fled amazed

"Leaves his stamp visibly upon the shore[.] (SPP 405-9)

This is Shelley's bleakest poem. Although Rousseau momentarily affirms revolutionary regeneration of human society through art - the "thousand beacons from the spark I bore" (207)-his example and that of those writers, thinkers, and politicians paraded behind the chariot confirm that self-division, disillusionment, and degeneration are norms that call into question (if they do not expose as illusion) Romantic, progressivist historiography. Rousseau as mouldy stump seems very different from the sage Shelley had deemed the "greatest man ... since Milton" (Shelley and His Circle 719), and whose lessons the "wise, and great, and good, / Interpret, or make felt, or deeply feel" ("Mont Blanc" 83-83, SPP). But rather than to suggest a late waning faith in the Romantic Imagination, this article considers the ways in which Shelley problematizes the suture between organic selfhood, individual consciousness, and social-political history, within a metaphorically rich discourse: palingenesis. This term is applied by the Swiss naturalist Charles Bonnet to proto-evolutionary history; by Herder and Kant to the unity of human consciousness over time; and by the French writer Pierre-Simon Ballanche to social evolution in a suffering post-revolutionary world. It also invokes alchemical transformations, bodily resurrection, and ghosts: imagery familiar to Shelleyans. Nevertheless, Shelley read 
neither Bonnet nor Herder; and he slightly predates Ballanche. So the purpose here is not to raise a phantom from long concealed source material, but to explore a discursive field in which Shelley's writings are embedded. Shelley's "Romantic palingenesis" is a discourse of rebirth or regeneration that stops short of a historiography of self or social being (a sceptical gesture Kant anticipates in the Critique of Pure Reason when he dissociates palingenetic theories from inner sense). ${ }^{1}$ Yet, while Kant considers "historical process" (in Hayden White's formulation) as "an inevitable degeneration under the appearance of progress" (White 56), Shelley inverts the proposition: history represents an inevitable progress under the appearance of degeneration (the fierce wolf”s "stamp” upon the shore). With Kant, however, Shelley conceives of history aesthetically, as a representation of the structures of temporal change, but adds to this the mysterious transhistorical hope that poetry might counterweight political degeneration. Romantic palingenesis represents this shift from regenerative theories of history and consciousness towards a sense that the unity of self and society is always contingent, never absolute.

Outside of and predating historiographical uses of palingenesis is its association with alchemy: specifically, experiments in which plants were said to be regenerated from their ashes. In a sketch entitled "Spectral Flowers," published in Robert Southey and Samuel Taylor Coleridge's Omniana in 1812, Southey quotes James Gaffarel's Unheard of Curiosities, translated from the French in 1650, which lays out the mechanics of this process:

"Though plants," he says, "be chopt in pieces, brayed in a mortar, and even burnt to ashes; yet do they nevertheless retaine, by a certaine secret and wonderfull power of nature, both in the juyce and in the ashes the selfe same forme and figure that they had before: and though it be not there visible, yet it may by art be drawne forth and made visible to the eye ...

Gaffarel gives the example of a "Polish physician" who holds the ashes of a rose "'over a lighted candle, ... [T] he ashes begin to move"” forming a "little dark cloud; which . . came at length to 
represent a rose; but so faire, so fresh, and so perfect a one, that you would have thought it to have been as substantial, and as odoriferous a rose as any that growes on the rose tree"" (213-14). Southey presents palingenesis as imposture written up in the jargon of science, but he is fascinated by the concept's plenitude, its application to explain "the ghosts of dead men ... seen to appear in churchyards" as "naturall effects, ... the formes of the bodies . . . buried in those places" (214), or to "a story of a sparrow resuscitated . . from its ashes." "So firmly was the Palingenesia believed by men of learning," Southey continues, "that it was frequently insisted on by divines as a proof of the immortality of the soul and the resurrection of the body" (219). Cotton Mather, with whom Southey concludes, draws a parallel between the chemist's art and that of the biographer: "we do in a book, as in a glass, reserve the history of our departed friends; and by bringing our warm affections unto such an history, we revive, as it were, out of their ashes the true shape of those friends, and bring to fresh view what was memorable and imitable in them" (220-21).

One senses that Mather's analogy between palingenesis and writing/memorial also lay behind Southey's attraction to this material (as much as his desire to expose vulgar errors). Palingenesis conceals its operations even as it insists on a scientific explanation for observable or posited phenomena; its power is in its representations of those phenomena, the sparrows, roses, and violets that expose the links between imagination and observation, poetry and science. The motivating energy of the process - heat, warmth, fire - anticipate Romantic fascination with sparks, lightening, and electricity as the sources of life, but also, with the affections or sensibility as the link between poets and readers across generations, the warmth transferred from the one to the other. For Shelley, the Romantic elegy and elegiac mode become means for exploring these 
affective identities; such works as Alastor or Adonais, in particular, become anxious invocations to the power of art to transcend the artist.

But Shelley's palingenetic metaphor might have been augmented by its application by Charles Bonnet to natural history. As a botanist, the discoverer of parthenogenesis in earthworms, and proponent of speculative science, Bonnet has been seen by Christa Knellwolf as the prototype for Professor Waldman, Victor's teacher in Frankenstein, a novel that takes issue with the dream of corporeal integrity in the palingenetic tradition; rather than a flower or sparrow regenerated from its own ashes, the monster is regenerated from the application of energy to spare body parts. ${ }^{2}$ Bonnet's Palingénésie philosophique (1769), however, is concerned with regeneration through cataclysm and revolution. Though a pre-formationist-Bonnet posits life as a germ present at the Creation and revealed through history like a series of "Russian dolls" (his term for this is "embôitment" [McCalla, "Palingenesie" 422])—Bonnet is also a protoevolutionist who posits a relationship between geophysical catastrophe and successive unfolding of higher intellectual powers not only in man but in all other links in nature's chain. In Bonnet's words:

Humanity, once transported to an abode more suited to the eminence of its faculties, will leave to the ape or the elephant that paramount place that it occupied among the animals of our planet. ... [T] herefore, it will be possible to find Newtons and Leibnizes among the apes or the elephants, Perraults or Vaubans among the beavers ... (qtd. and trans. in McCalla, "Palingenesie" 425)

While inevitably progressivist and uni-directional, history for Bonnet does not do away with suffering, violence, decline, revolution, or catastrophe, and the direction of palingenetic theorizing among scientists, philosophers, and poets after Bonnet increasingly emphasises these obstacles; Palingénésie philosophique contains the seeds of its own dissolution. 
While Bonnet's writings attempt to ground his hypotheses in observable phenomena, a corollary to his thinking is memory. As Arthur McCalla observes, Bonnet regarded memory as a physical "key to personality. His particular concern was that memory should survive death" ("Palingenesie" 423). Though an empiricist, Bonnet nevertheless posits a "Structure primordiale" in the nerve fibre (1: 15), a kind of genetic code determining the timbre and capacity of memory: "Dispositions ou de Déterminations" (1: 19). ${ }^{3}$ The proximity of Bonnet's reflections to ideas of metempsychosis links his thinking with Herder's Über die seelenwanderung (1782), where Herder posits a natural palingenesis ("wahre Palingenesie dieses Lebens" [qtd. in Barry 19n11]) in which memory bridges the gap between fragments of self within a single life (rather than being the means by which the soul preserves memory between lives). In Herder's view palingenesis explains how, quite literally, "the child is father of the man"; childhood memories provide a unity of identity over time and particularly in old age (whereas Kant figures this "rebirth" into the absolute unity of determined character as an "explosion" or "revolution" occurring in most only after the age of 40 [Kuehn 144-50]). Perhaps with Herder in mind, Shelley's close friend Horace Smith later wrote:

A man of eighty may forget that he was seventy, but he never forgets that he was once a boy. Who can doubt the immortality of the soul, when we see that the mind can thus pass out of bodily decrepitude into a state of rejuveniscence? for this process amounts to a Palingenesia - a partial new birth out of a partial decease, preparatory to a total resurrection out of total dissolution. (2:25)

In his article on palingenesis in Herder and Jean Paul, to which I am indebted here, Kelly Barry suggests further that Jean Paul's satire, Leben des Quintus Fixlein (1797), posits a question that, as we shall see, also informs Shelley's work: "can memory, in its power to hold a self together, even revive a body?" (3). 
Such theories skirt the problematic relationship between social and political revolutions and regeneration, a question addressed directly by Pierre-Simon Ballanche in his fragmentary Essais de palingenesie sociale, published in part in 1827 and 1829. Describing his theory, in the opening dedication, as "la grande pensée de mon siècle" ([v]), Ballanche undertakes to demonstrate that history itself (rather than the human organism) expresses the progressive or evolutionary regeneration of God's plan, and that revolutionary violence and suffering are necessary (as expiation); in total, social history adapts the divine plan to the capacities of human thought (a sociological “embôitment”). For Ballanche, the French Revolution provides the principle model in which, out of apparent chaos, bloodshed, irreligion, and suffering, emerges or evolves such a social movement. Like Bonnet, Herder, and Kant before him, Ballanche finds in palingenesis a metaphor for cohesion and social rebirth, yet, as Lynn Sharp has argued, he took "the motor of progress away from humanity and gave it back to God," with the social world revealing the "primacy of suffering to that progress" (13). Ballanche's regeneration can look, to living observers, like degeneration, and this severing of tenor from vehicle brings us back to Romantic palingenesis and Shelley.

It is tempting to imagine palingenesis among the topics of conversation during Shelley's first meeting with Southey in December 1811, not long before the Omniana went to press. One of his letters from this time certainly sounds Bonnet-like in its speculations on life and death: "I think reason and analogy seem to countenance the opinion that life is infinite - that as the soul which now animates this frame was once the vivifying principle of the infinitely lowest link in the Chain of existence, so is it ultimately destined to attain the highest" (Letters 1: 215). ${ }^{6}$ While Bonnet's chain is fixed, Shelley's is fluid, and Shelley's solution to the unbridgeable distance between the Chain's highest link and First Cause is to dispense with the latter. In Queen Mab 
(1813) and its subsequent revision as "The Daemon of the World" (1816) and related drafts, ${ }^{7}$

Shelley considers the more openly materialist palingenesis of Baron d'Holbach's System de la nature (1770):

La nature entiere ne subsiste \& ne se conserve que par la circulation, la transmigration, l'échange \& le déplacement perpétuels des molécules \& des atômes insensibles ou des parties sensibles de la matiere. C'est par cette palingénésie que subsiste le grand tout, qui, semblable au Saturne des anciens, est perpétuellement occupé à dévorer ses propres enfans. $(149)^{8}$

The whole of nature subsists, and is conserved only by the circulation, the transmigration, the exchange, the perpetual displacement of insensible atoms, the continual mutation of the sensible combinations of matter. It is by this palingenesia, this regeneration, that the great whole, the mighty macrocosm subsists, who like the Saturn of the ancients, is perpetually occupied with devouring her own children. (Nature 2: 138)

In Queen Mab, Saturn becomes "Time"_-refigured as "hoary giant Time" in the Daemon Draft-and is called upon by Mab to "render up thy half-devoured babes" who sleep by the "deep murmuring stream of passing things" (Complete Poetry [hereafter CP] 2: 222, canto 8, lines 38). ${ }^{9}$ While Holbach's Saturnian metaphor indicates that blind agency (Necessity) might appear less than indifferent, even destructive, mirroring the worst of human affairs, Shelley's equivocations are more overt. He envisions a "renovated world" (CP 3: 56) accessible to the visionary, yet draws a parallel between corporeal ruin of the body in death and the sleeping Ianthe figured as a "marble column" around which her "golden tresses" twine "like tendrils of the parasite," an image prefiguring another kind of ruin (architectural/historical) which nevertheless supports life and regeneration. The dreamer awoken, in turn, undergoes a brief shudder ("a gentle start convulsed Ianthe's frame"10), a second birth or palingenesis, in which dream vision becomes woven into the unity of unconsciousness in the politicized life well-led.

In The Daemon of the World fragment that concludes the Alastor volume, however, "loathsomeness and ruin" (CP 3: 44, line 20) are always close at hand. The Daemon, refigured as 
a "shape" 59, 71) whose chariot is drawn by "four shapeless shadows" (64), descends upon the sleeping Ianthe to unfold "all [that] thy memory doth inherit / From ruin of divinest things" (8081), an early suggestion in Shelley's verse that memory might be transhistorical rather than personal, the accumulation of historical as well as sensory input. The fragment ends differently, though, for Ianthe's "ecstasy" (253) at viewing the "wilderness of harmony" (249) from the “overhanging battlements" (24) of the universe gives way to a long passage of new material in which Ianthe perceives within this harmony "fiendly shapes, / Thronging round human graves" that "Sculptur[e] records for each memory / In verse" (259-60). This "Gothic passage" anticipates the "grotesque scenes in PBS's mature poetry" (CP 3: 447), but it also emphasises the opening distance between ideal states and reality (and here, too, the possibility that memory is the sum total not only of historical refinement but also of degenerate memorializing). The final line's invocation to "Necessity's unchanging harmony" thus strikes a less certain note than in Queen Mab where the poetry was freighted with didactic prose. This Daemon, "serene and inaccessibly secure" (286), looks forward to the Shelley's skeptical-idealist Power in "Mont Blanc," "Remote, serene, and inaccessible" (SPP 97).

While "The Daemon of the World" is a more fitting end to the volume (and a more functional poem) than it has been generally considered, the volume's title poem concentrates more of Shelley's palingenetic speculations than any of his poems to date. Alastor consists of a narrator's lament over another "surpassing spirit," the dead poet who leaves little record of himself. In the opening invocation to Nature, the narrator establishes himself as a metaphysical enquirer seeking among the boundaries of life and death some sign of regeneration, of the translatability of life beyond the grave: "forcing some lone ghost / ... to render up the tale / Of what we are" (CP 3: 9, lines 27-29). Nature remains silent, the narrator's palingenetic impulses 
thwarted, the warmth of his affections - heightened to incestuous eroticism—not enough to reanimate the dead. The fear of a similar failure with regards to the memory of the Poet he eulogises drives the rest of the poem.

Nurtured by "the vast earth and ambient air," "fountains of divine philosophy," "and all of great, / Or good, or lovely, which the sacred past / In truth or fable consecrates" (69-74), the Poet represents more than an individual, embodying rather the transhistorical, palingenetic potential of Poetry itself for ensuring social, political, and intellectual rebirth (the prototype for that celebrated by the Defence). Yet in Alastor, the narrator couches these ideals in another narrative of decay and degeneration; his opening image of “autumnal winds / Buil[ding] o'er [the Poet's] mouldering bones a pyramid / Of mouldering leaves in the waste wilderness" (52-54) underscores the transience of the human body, monumental architecture, and nature itself. More alarming for the narrator is the loss of the Poet's voice and identity, as the narrator's own words anxiously, at times plaintively, attempt to fill these spaces.

The Poet's degeneration is the story of his refusal to embody in human or social forms his ideals of love, liberty, and poetry. In his relentless pursuit of "Vision and Love" (366) towards the border of "Sleep and death" (368), the poet's vital flame decays, his body withers, nature gradually mirroring his privations in its own sublimity, until the place of death is achieved, a nook beneath a rock-rooted pine where the Poet "scatter[s his] music on the unfeeling storm" (597). The moment of death is imaged as extinction, an absolute zero: "No sense, no motion, no divinity — / . . / Still, dark, and dry, and unremembered now" $(666,671)$. This is also the moment of desire at its most plangent. "O, for Medea's wondrous alchemy," cries the narrator, "Which wheresoe'er it fell made the earth gleam / With bright flowers, and the wintry boughs exhale / From vernal blooms fresh fragrance" (672-75): 
$\ldots$ O, that the dream

Of dark magician in his visioned cave,

Raking the cinders of a crucible

For life and power, even when his feeble hand

Shakes in its last decay, were the true law

Of this so lovely world! (681-86)

In the Defence, the flower/crucible image compares translation to alchemical experiments on flowers that regenerate forms without fragrance, yet original poetry works otherwise: "[The poet] beholds the future in the present, and his thoughts are the germs of the flower and the fruit of latest time" (SPP 483). The Alastor narrator, however, reminds us that we are in the realms of Romantic palingenesis where the desire for translation, transfusion, and transhistorical regeneration alone must suffice for a world in which the "true law" seems (but cannot be proved to be) otherwise.

In "The Triumph of Life," Rousseau enjoins the "shape all light" to "pass not away upon the passing stream," an image that recalls the "deep murmuring stream of passing things" of Queen Mab and the Daemon Draft. In all of these instances Shelley uses the stream as a metaphor for the imbrication between time and materiality, for which, in the Daemon Draft, he attempts to overlay the possibility of a palingenetic awakening or rebirth commensurate to the new life of the individual: "For birth but wakes the universal Spirit Mind / Whose mighty streams might else in silence flow / Through the vast world, to individual sense" (CP 3: 64, lines 248-50). Like Alastor, however, Shelley's last poem resists the kind of visionary certainties that seem so cumbersome in Queen Mab. The biographical urge to discover a palingenetic faith embodied in the Poet's life story, thwarted in Alastor, is also evident in "The Triumph" and to the same results. Neither "Medea's wondrous alchemy" of the one poem nor the "vital alchemy" (SPP 402) of the other provide the consolations or certainties that their respective narrators seek, and, in "The Triumph," embôitment gives way to a house of mirrors in which the narrator's 
vision of the triumphal procession (mediated by Rousseau) reflects Rousseau's vision of the same madness (mediated by the "shape all light"). How, to what extent, and whether there will be an escape to a position of clarity from these repetitions, all remain unknown and unknowable.

The fragmentary form of "The Triumph," "The Daemon of the World," and Daemon Draft, seems particularly suited to Romantic palingenesis, itself concerned with recovering, revivifying, or remotivating fragments, ashes, remains, and remainders. Perhaps the most knowing successor to this quasi-tradition of Romantic discourse, Thomas Carlyle's Sartor Resartus (1833-34), consciously manipulates its full plenitude of metaphoric and narrative possibilities adding to it a satiric or at least facetious tone. Once again, a narrator attempts to recover the life story of a "surpassing spirit," the clothes-philosopher Teuflesdröckh, the near impossible task of piecing together the miscellaneous contents of "Six considerable PAPERBAGS" (60); and again the narrator has recourse to meditations on ghosts, alchemy, and poetry in his attempts to reconstruct from these fragments the clothes-philosophy of his subject. What is new is the fact that Carlyle's narrator identifies the telos of Teuflesdröckh's philosophical work as its missing "Second Volume, On the Palingenesia, or Newbirth of Society" (164), putting a name to the philosophical underpinnings that are only implicit in Shelley. ${ }^{11}$ Despite the radical differences between Shelley's and Carlyle's worldviews - the two authors are rarely discussed together-the proximity of Sartor and Shelley's works deserve further attention as does the identification of other works of Romantic palingenesis: where the ideals of integration, rebirth, and progress — in human life and political society — come up against the limits of narrative, contingence, unknowability, and failure.

\section{Notes}


${ }^{1}$ See Kant (558): "For no empirical laws of bodily appearances, which are of a totally different kind, will then intervene in the explanation of what belongs exclusively to inner sense. No windy hypotheses of generation, extinction, and palingenesis of souls will be permitted. The consideration of this object of inner sense will thus be kept completely pure and will not be confused by the introduction of heterogeneous properties."

${ }^{2}$ Knellwolf speculates that Bonnet - whose base in Switzerland was not far from where the Shelleys resided in the summer of 1816 - may have been a model for Professor Waldman, both being figures of "intellectual courage" in pursuing speculations beyond empirical data. Bonnet wrote, "One may not have too many conjectures on an obscure subject . . Conjectures act as sparks which may kindle a torch that can lead the way to new experiments . . I cannot condemn the ingenious rashness of those who sometimes attempt to penetrate beyond [the facts]" (Charles Bonnet, Considérations sur les corps organisés (1768), qtd. and trans. in Knellwolf 61).

${ }^{3}$ See also volume 1, page 17: 'Il m'a paru, que puisque ce Souvenir tient au Corps, il devoit dependre de quelque changement qui survenoit à l'état primitif des Fibres sensibles, par l'action des Objets" "it appeared to me, that since this Memory belongs to the Body, it must depend on some change that occurred in the primitive state of the sensible fibres, by the action of objects' (my trans.).

${ }^{4}$ See Barry for a useful summary of the intellectual dialogues informing Herder's discussion (1920n10). See also Nisbet: "In his Gespräche über die Seelenwanderung of 1785, he says more cautiously that true palingenesis is the regeneration of the individual man in this life, and that a higher but unknown palingenesis doubtless occurs after death too" (234).

${ }^{5}$ For the fullest treatment of Ballanche's theories to date, see McCalla, Romantic Historiosophy. 
${ }^{6}$ The quotation continues: " - that every thing is animation (as explained in my last letter) and in consequence being infinite we can never arrive at its termination. How, on this hypothesis are we to arrive at a first cause?" (1:215).

${ }^{7}$ In the discussion below, I follow Complete Poetry in distinguishing between $Q u e e n$ Mab (1813), the revisions to cantos 1 and 2 published in the Alastor volume as "The Daemon of the World" (1816), and the unpublished revisions of canto 5, lines 1-15 and cantos 8-9, or Daemon Draft, most likely dating "between September 1815 and January 1816 (3: 461).

${ }^{8}$ Shelley used the 1781 edition cited here in his notes to Queen Mab (see Complete Poetry 2: 615).

${ }^{9}$ Cf. Daemon Draft: 'Thou hoary giant Time, / Render thou up thy half-devoured babes,- / And from the cradles of eternity, / Where millions lie lulled to their portioned sleep / By the deep murmuring stream of passing things, / Tear thou that gloomy shroud. - Spirit, behold / Thy glorious destiny! The Spirit feltsaw / The vast frame of the renovated world / Smile in the lap of Chaos ... (CP 3: 56: 28-36). The parts here not italicized are unchanged from Queen Mab, canto 8, lines 5-10 (CP 2: 222), but this was a passage that Shelley had earmarked for development, and is preceded by important additions that, as the editors remark, attempt to tone down the antiChristian elements while drawing on a Lucretian world view. The connection to d'Holbach's passage on palingenesis hitherto has been overlooked in the textual history of these lines, although Matthews and Everest do cite the original French passage as a gloss to the opening lines of Queen Mab, canto 5 (Poems 1: 309 v 3n).

${ }^{10}$ CP 3: 66: Daemon Draft, line 325 (unchanged from CP 2: 237: Queen Mab 9.233).

${ }^{11}$ While Smeed notes the influence of Jean Paul Richter on the style and structure of Sartor Resartus, not least Jean Paul's Quintus Fixlein, he does not go as far as Barry to link Richter's 
novel to palingenetic discourse. A full explication of this important context for Sartor has yet to be written.

\section{References}

Ballanche, Pierre-Simon. Essais de palingénésie sociale. Vol. 1. Paris: Jules Didot ainé, 1827. Print.

Barry, Kelly. "Natural Palingenesis: Childhood, Memory and Self-Experience in Herder and Jean Paul." Goethe Yearbook 6 (2007): 1-25. Proquest Literature Online. Web. 11 Jan. 2017.

Bonnet, Charles. La palingénésie philosophique, ou idées sur l'état passé et sur l'état futur des etres vivans. Ouvrage dstiné à servir de supplement aux derniers essais de l'auteur. 2 vols. Munster: chez Philippe Henry Perrenon, 1770. Google Books. Web. 11 Jan. 2017.

Carlyle, Thomas. Sartor Resartus. Ed. Kerry McSweeney and Peter Sabor. Oxford: Oxford UP, 2008. Print,

D'Holbach, Paul Henri Thiry. Nature, and Her Laws: As Applicable to the Happiness of Man, Living in Society. 2 vols. London: James Watson, 1834. Print.

—. Systême de la nature, ou des loix du monde physique \& de monde moral. London, 1781.

Print.

Kant, Immanuel. Immanuel Kant's Critique of Pure Reason. Trans. Norman Kemp Smith. Basingstoke: Macmillan, 1985. Print.

Knellwolf, Christa. “Geographic Boundaries and Inner Space: Frankenstein, Scientific Explorations and the Quest for the Absolute." Frankenstein's Science: Experimentation 
and Discovery in Romantic Culture, 1780-1830. Ed. Knellwolf and Jane Goodall. Aldershot: Ashgate, 2008. Print.

Kuehn, Manfred. Kant: A Biography. Cambridge: Cambridge UP, 2001. Print.

McCalla, Arthur. "Palingenesie Philosophique to Palingenesie Sociale: From a Scientific Ideology to a Historical Ideology." Journal of the History of Ideas 55.3 (1994): 421-39. Print.

—. A Romantic Historiosophy: The Philosophy of History of Pierre-Simon Ballanche. Leiden: Brill, 1998. Print.

McGann, Jerome J. The Romantic Ideology: A Critical Investigation. Chicago and London: $\mathrm{U}$ of Chicago P, 1983. Print.

Nisbet, H. B. Herder and the Philosophy and History of Science. Cambridge: Modern Humanities Research Association, 1970. Print.

Sharp, Lynn L. Secular Spirituality: Reincarnation and Spiritism in Nineteenth-Century France. Plymouth: Lexington Books, 2006. Print.

Shelley and His Circle 1773-1822. Ed. Donald H. Reiman. Vol. 7. Cambridge, MA: Harvard UP, 1986. Print.

Shelley, Percy Bysshe. The Complete Poetry of Percy Bysshe Shelley. Gen. ed. Donald H. Reiman, Neil Fraistat, and Nora Crook. Vols. 2-3. Baltimore: The Johns Hopkins UP, 2004-2012.

—. The Letters of Percy Bysshe Shelley. Ed. Frederick L. Jones. 2 vols. Oxford: Clarendon Press, 1964. Print.

—. The Poems of Shelley. Ed. Geoffrey Matthews and Kelvin Everest. Vol. 1. London and New York: Longman, 1989. Print. 
—. Shelley's Poetry and Prose. 2nd ed. Ed. Donald H. Reiman and Neil Fraistat. New York and London: W. W. Norton \& Co., 2002. Print.

Smeed, J. W. “Thomas Carlyle and Jean Paul Richter.” Comparative Literature 16.3 (1964): 226-53. Print. Proquest Literature Online. Web. 11 Jan. 2017.

Smith, Horace. The Tin Trumpet, or Heads and Tales, for the Wise and Waggish. 2 vols. London: Whittaker and Co., 1836.

Southey, Robert, and Samuel Taylor Coleridge. Omniana, or Horae Otiosiores. Ed. Robert Gittings. Carbondale: Southern Illinois UP, 1969. Print.

White, Hayden. Metahistory: the Historical Imagination in Nineteenth-Century Europe. Baltimore: Johns Hopkins UP, 1973. Print. 